\title{
PEMIKIRAN PENDIDIKAN ISLAM IBN SAHNÛN: Analisis Kritis Kurikulum Pengajaran di Institusi Pendidikan Dasar Islam
}

\author{
Syahrizal \\ Jurusan Tarbiyah STAIN Malikussaleh Lhokseumawe \\ Jl. Cempaka No. 1 Lancang Garam, Lhokseumawe, 24300 \\ e-mail: albireuni@gmail.com \\ Rabiatul-Adawiah Ahmad Rashid \\ School of Educational Studies, Universiti Sains Malaysia, 11800 USM, Penang \\ e-mail: r_adawiah@usm.my
}

\begin{abstract}
Abstrak: Tulisan ini bertujuan mengungkapkan relevansi pemikiran Ibn Sahnûn mengenai kurikulum pengajaran pendidikan dasar Islam dengan praktik kurikulum pengajaran pada institusi-institusi pendidikan dasar Islam masa kini. Berdasarkan analisis deskriptif, analisis isi, dan analisis kritis, penulis berargumen bahwa kurikulum pengajaran pendidikan dasar Islam menurut Ibn Sahnûn masih relevan dengan praktik kurikulum pengajaran pendidikan dasar Islam masa kini. Hal tersebut setidaknya berdasarkan: 1) aspek prinsip penyusunannya, yaitu prinsip tawâzun (keseimbangan) antara materi-materi ukhrawi dengan duniâwi, intelektual dengan spiritual, materimateri teoretis dengan praktis, dan prinsip relevansi, yaitu kesesuaian kurikulum pengajaran dengan kebutuhan masyarakat, dan 2) dari aspek dasar utama yang menjadi landasan penyusunan kurikulum pengajaran, yaitu dasar agama dan sosial.
\end{abstract}

\begin{abstract}
Ibn Sahnûn's Islamic Educational Thought: Critical Analysis of Teaching Curriculum in the Institution of Islamic Elementary Education. This paper aims to reveal the relevance of Ibn Sahnûn thought on teaching curriculum of Islamic primary education to the practice of the current teaching curriculum in Islamic primary education institutions. Based on descriptive, content, and critical analysis to form a reflective thought, the results of present study showed that the teaching curriculum of Islamic elementary education of Ibn Sahnûn still relevant to the practice of it nowadays, especially from (1) the principles of it composition aspects, the principle of tawâzun (equilibrium) between the materials of the hereafter with worldly ones or (intellectual with the spiritual aspect), the theoretical material with practical, and the principle of relevance, the suitability of the teaching curriculum to the needs of the community, and (2) the primary basis on which the teaching curriculum is developed, which is the basis of religion and social issues.
\end{abstract}

Kata Kunci: Ibn Sahnnûn, kurikulum pengajaran, pendidikan dasar Islam 


\section{Pendahuluan}

Sebagai tokoh pendidikan Islam, Ibn Sahnûn banyak memberikan perhatian kepada proses pendidikan dan pengajaran tingkat dasar. Ide-ide Ibn Sahnûn tentang pendidikan dasar, secara khusus terkandung dalam karya monumentalnya, Âdâb al-Mu'allimîn (Adab Para Guru) atau The Book of Teacher's Morals atau The Moral Code of Teachers. ${ }^{1}$ Sungguhpun Ibn Sahnûn merupakan seorang tokoh yang sangat populer di zamannya, tetapi ide-idenya, khususnya tentang pendidikan, masih kurang mendapat perhatian para peneliti. Kajian ilmiah yang membahas ide-ide Ibn Sahnûn tentang pendidikan, baik dalam bentuk buku, jurnal, paper, maupun dalam bentuk lainnya, masih sedikit dan terbatas. ${ }^{2}$ Kajian-kajian tersebut secara umum masih bersifat deskriptif dan kurang dianalisis secara kritis, khususnya tentang kurikulum pengajaran di Kuttâb (institusi pendidikan dasar Islam).

Menurut Ali Asyraf, mengkaji turâts pemikiran klasik-apapun gagasannya-sah-sah saja, manakala disertai sikap kritis sehingga tidak hanya memperlihatkan yang baik-baik saja, tapi juga kekurangan-kekurangannya kalau memang ada. Kalaupun hal itu diterima tentu setelah melalui proses penyelidikan yang mendalam, sebab pemaknaan ilmuan manapun terhadap suatu teori perlu dianalisis dan diuji oleh ilmuan berikutnya. ${ }^{3}$ Untuk keseimbangan dan keadilan, maka pemikiran seorang tokoh, di samping mencari sisi kelebihannya juga menemukan sisi kelemahannya, termasuk juga pemikiran pendidikan Ibn Sahnûn.

Pentingnya kurikulum pengajaran dikaji karena kurikulum merupakan bagian dari faktor yang sangat menentukan dan "memberikan makna terhadap proses pendidikan dan pembelajaran di lembaga pendidikan, sehingga dimungkinkan terjadi adanya saling interaksi antara pendidik dengan anak didik."4 Maksudnya, dalam proses pendidikan, di manapun pendidikan diselenggarakan harus jelas kurikulum pengajaran yang didesain dan dipraktikkan. Karenanya, dalam konteks itu, tulisan ini coba menjawab pertanyaan bagaimana relevansi pemikiran Ibn Sahnûn mengenai kurikulum pengajaran pendidikan dasar Islam dengan praktik kurikulum pengajaran pada institusi-institusi pendidikan dasar masa kini?

${ }^{1}$ Sya'ban Muftah Ismail, "Muhammad Ibn Sahnun: An Educationalist and a Faqih," dalam Muslim Education Quarterly, Vol. XXII, No. 4 (U.K.: The Islamic Academy, Cambridge, 1995), h. 44.

${ }^{2}$ Beberapa penelitian yang telah dilakukan para ahli tentang pemikiran pendidikan Ibnu Suhnûn antara lain kajian Ibrâhîm Muhammad Syâfiî̀ dalam Min Alâm al-Tarbiyah al-Arabiyah al-Islâmiyah (Maktabah al-Tarbiyah al-'Arabî li Duwal al-Khalîj, 1988), h. 247-275, A. Susanto dalam Pemikiran Pendidikan Islam (Jakarta: Amzah, 2009), h. 54-60, Gamal Abdul Nasir Zakaria dalam Prinsip-Prinsip Pendidikan Islam; Ibnu Sahnun, al-Qabisi, Ibnu Khaldun (Pahang Darul Makmur: PTS Publications \& Distributors SDN BHD, 2003), h. 1-67, Sya'ban Muftah Ismail dalam "Muhammad Ibn Suhnun: An Educationalist and a Faqih," Muslim Education, h. 37-54, dan 'Abd al-Amîr Z. Syams al-Dîn dalam Al-Fikr al-Tarbawi 'inda Ibn Suhnûn wa al-Qâbisî, alThab'ah al-Ulâ (Bairut: al-Syirkah al-Islamiyah li al-Kitâb, 1990), h. 53-74.

${ }^{3}$ Ali Asyraf, Horizon Baru Pendidikan Islam (t.t.p.: Pustaka Firdaus, 1996), h. 40.

${ }^{4}$ Arief Furchan et al, Pengembangan Kurikulum Berbasis Kompetensi di Perguruan Tinggi Islam (Yogyakarta: Pustaka Pelajar, 2005), h. 5. 
Dalam rangka menjawab pertanyaan tersebut, akan digunakan metode deskriptif, analisis isi, analisis kritis, dan analisis reflektif. Metode deskriptif digunakan untuk mendeskripsikan profil Ibn Sahnûn dan pemikirannya tentang kurikulum pengajaran di institusi pendidikan dasar pada masanya. Metode analisis isi (content analysis) digunakan untuk menelaah karya Ibn Sahnûn, khususnya Kitâb Âdâb al-Mu'allimîn untuk menemukan pemikirannya tentang kurikulum pengajaran di lembaga pendidikan dasar Islam. Kemudian data yang diperoleh dianalisis secara kritis untuk menemukan kelebihan dan kekurangannya, kalau memang ada. Selanjutnya akan dilakukan analisis reflektif untuk menemukan mana pemikiran Ibn Sahnûn tersebut yang pantas dipertahankan dalam praktik kurikulum pendidikan dasar sekarang dan mana yang perlu dibenahi.

Dengan demikian, maka pembahasaan dalam tulisan ini terfokus pada kurikulum pengajaran menurut Ibn Sahnnûn. Uraian pembahasan inti mencakup profil Ibn Sahnûn, Kuttâb sebagai institusi pendidikan dasar Islam, praktik kurikulum pengajaran di institusi pendidikan dasar Islam sebelum dan pada masa Ibn Sahnûn, pemikiran Ibn Sahnûn tentang kurikulum pengajaran, dan rekomendasi serta kritik terhadap kurikulum pengajaran Ibn Sahnûn.

\section{Profil Ibn Sạnûn, Kuttâb, dan Kurikulum Pengajaran Biografi Ibn Sahnûn}

Nama lengkap Ibn Sahnûn adalah Abû 'Abdillah Muhammad bin Abî Saî̀d Sahnûn.

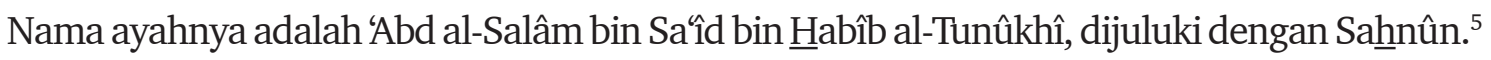
Abû 'Abdillah Muhammad bin Abî Sa 'î̀ Sahnûn lebih dikenal dengan nama Muhammad bin Sahnûn atau Ibn Sahnnûn, lahir di kota Ghadat (pusat kebangkitan mazhab Mâlikî di Maghrib), ${ }^{6}$ Qairawân ${ }^{7}$ pada tahun 202 H (pada awal abad ke- 3 H/ abad ke-9 M). ${ }^{8}$ Tanggal dan bulan kelahirannya secara tepat tidak diketahui dan tidak dapat dijumpai, baik di dalam kitabkarangannya sendiri maupun di dalam buku penulis lain yang menulis tentang Ibn Sahnûn.

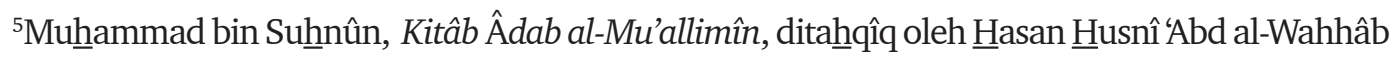
dan cetakan baru dengan murâja'ah dan komentar Muhammad al-Arûsî al-Mathwî, (Tûnis: Dâr Bûsalâmah li al-Thab'ah wa al-Nasyr wa al-Tauzî', t.t.), h. 15. Suhnûn artinya seekor burung yang memiliki pandangan yang tajam. 'Abd al-Salâm (ayah Ibnu Suhnûn) terkenal dengan gelar ini karena ketajaman pemikirannya. Lihat A. Susanto, Pemikiran Pendidikan Islam (Jakarta: Amzah, 2009), h. 55.

${ }^{6} \mathrm{Ibid}$.

${ }^{7}$ Kota Qairawân dibangun atas saran panglima 'Uqbah bin Nâfi' kepada para sahabatnya. Setelah dilakukan perundingan maka akhirnya kota tersebut dibangun antara laut dan kawasan yang tidak dapat dijangkau oleh tentara laut. 'Uqbah memilih kawasan pembangunan kota baru itu karena lokasinya sangat strategis, terletak di antara pantai dan padang pasir, jauh dari serangan bala tentara Byzantium dari arah pantai dan juga pasukan tentara Barbar dari arah padang pasir. Lihat Gamal Abdul Nasir Zakaria, Prinsip-Prinsip Pendidikan Islam; Ibnu Sahnun, al-Qabisi, Ibnu Khaldun (Pahang Darul Makmur: PTS Publications \& Distributors SDN BHD, 2003), h. 2.

'Ibrâhîm Muhammad Syâfi'î, Min A lâm al-Tarbiyah al-Arabiyah al-Islâmiyah (Maktabah al-Tarbiyah al-'Arabî li Duwal al-Khalîj, 1988), h. 47.
} 
Qairawân, tempat Ibn Sahnûn dilahirkan dan dibesarkan merupakan negeri yang terkenal dengan julukan Dâr al-Sunnah (negeri sunnah) karena banyak didatangi oleh pelajar-pelajar ilmu syarî‘at dari seluruh pelosok Maghrib (Marokko). ${ }^{9}$ Qairawân terletak di Afrika Utara pada era penyebaran Islam. Wilayah ini dijadikan sebagai lintasan untuk menaklukkan negerinegeri Maghrib. Qairawân terkenal dengan negeri yang memiliki peradaban tinggi setelah berdirinya tiga dinasti pemerintahan yang besar dalam sejarah Maghrib, yaitu Dinasti Aqabah, Fâthimiyah, dan Sanhajiyah. ${ }^{10}$ Justeru, pada zamannya, Qairawân termasuk kota maju di wilayah Maghrib terutama dalam bidang ilmu pengetahuan syarî‘at.

Pendidikan pertama yang diperoleh Ibn Sahnûn adalah dari ayahnya sendiri, Sahnûn ibn Sahnûn ibn ㅂabî̉b ibn Râbi'ah al-Tanûkhî (160-240H), salah seorang fakîh dan tokoh mazhab Mâlik yang terkenal di Afrika Utara. ${ }^{11}$ Pelajaran pertama dipelajari Ibn Sahnûn adalah al-Qur'an dan dasar-dasar membaca di pusat pendidikan dasar Islam (Kuttâb). ${ }^{12}$

Di bawah asuhan dan bimbingan ayahnya, Ibn Sahnûn besar menjadi anak yang cerdas dan pintar. Karena itu, dapat dikatakan bahwa ayahnya adalah orang pertama yang memiliki pengaruh sangat kuat terhadap pembentukan kepribadian dan pola pemikiran kependidikan Ibn Sahnûn. ${ }^{13}$ Selain ayahnya, Ibn Sahnûn juga berguru kepada beberapa ulama-ulama lain yang ada di Maghrib (Marokko), ${ }^{14}$ Mesir, ${ }^{15}$ dan Masyriq (termasuk Makkah dan Madinah). ${ }^{16}$ Ini menunjukkan bahwa dari segi pendidikan, Ibn Sahnûn menempuh pendidikan dalam dua tahap penting, pertama, menghapal al-Qur'an dan memperoleh ilmu-ilmu penting yang berhubungan dengan al-Qur'an, dan kedua, mendalami ilmu-ilmu syarî‘at, bahasa, sejarah, dan ilmu-ilmu lain di bawah bimbingan ayah dan guru-gurunya yang terkenal di Maghrib, Mesir, dan Masyriq tersebut. ${ }^{17}$

Sebagai seorang ulama dan pendidik terkenal, banyak orang yang datang ingin berguru

9'Ibnu Suhnûn, Kitâb Âdâb, h. 15.

${ }^{10}$ Suwito dan Fauzan (ed.), Sejarah Pemikiran Para Tokoh Pendidikan (Bandung: Angkasa, 2003), h. 51.

${ }^{11}$ Ibid, h. 50

${ }^{12}$ Kuttâb adalah sejenis tempat belajar yang mula-mula lahir di dunia Islam. Perkataan "kuttâb" ini diambil dari "taktîb" (mengajar menulis), dan mengajar menulis itulah fungsinya kuttâb itu. Tapi, oleh karena yang belajar pada kuttâb itu adalah anak-anak, sedang anak-anak pulalah yang belajar pada tempat (jenis) yang satu lagi, yaitu tempat mengajarkan al-Qur'an dan agama, karena itu tempat mengajarkan al-Qur'an dan agama ini dinamakan pula "kuttâb". Kemudian tersiarlah nama kuttâb itu dengan arti "tempat anak-anak belajar", biarpun yang diajarkan di situ al-Qur'an, ataupun menulis dan membaca. Lihat Ahmad Syalabi, Sejarah Pendidikan Islam, terj. Muchtar Jahja dan Sanusi Latief (Singapura: Pustaka Nasional, 1976), h. 23.

${ }^{13}$ Suwito dan Fauzan (ed.), Sejarah, h. 51-52.

${ }^{14}$ Di antara guru-gurunya di Marokko adalah Mûsâ bin Mu'âwiyah al-Shamâdahî, 'Abd al 'Azîs bin Yahyâ al-Madanî, dan 'Abdullah bin Abî Hasan al-Yasabî.

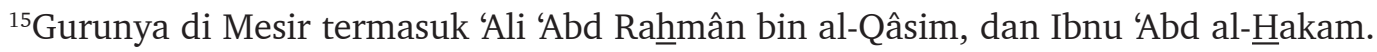

${ }^{16}$ Gurunya di Makkah adalah ulama-ulama Makkah, dan gurunya di Madinah antara lain Abu Ma'ab Ahmad bin Abî Bakr al-Zuhrî.

${ }^{17}$ Syafi'i, Min al-Alâm, h. 237. 
kepada Ibn Sahnûn. Di antaranya Muhamammad bin Sâlim al-Qaththân dari Qairawân, ${ }^{18}$ al-Muznî (sahabat Imam Syâfi'i), ${ }^{19}$ dan Harun bin Saî̀d al-'Alî (kedua nama terakhir ini adalah murid-murid Ibn Sahnûn ketika berada di Mesir).

Di samping mengajar, Ibn Sahnûn juga aktif menulis. Karya-karyanya mencapai 200, di antaranya adalah ${ }^{20}$ (1) al-Jâmi', merupakan karyanya terbesar yang mengandung berbagai disiplin ilmu, terdiri lebih dari 100 juz, di antaranya 20 juz tentang biografi, 25 juz tentang al-Amtsâl (perumpamaan), 10 juz tentang adab mengambil keputusan, 50 juz tentangfarâidh, 8 juz tentang sejarah dan biografi para tokoh, dan sisanya tentang disiplin ilmu lainnya. Kitab tersebut bisa dikatakan semacam ensiklopedi ilmu pengetahuan lengkap yang ada pada masa itu; (2) al-Musnad, kitab hadis yang sangat tebal; (3) Tahrîm al-Muskir; (4) al-Imamah. Al-Qâdhî 'Isâ bin Miskîn berkata: "Ketika kitab al-Imamah yang dikarang oleh Muhammad bin Sahnûn sampai ke Baghdad, kitab itu ditulis dengan tinta emas dan dihadiahkan kepada khalifah" (5) Masâ'il al-Jihâd, 20 juz; (6) Tafsîr al-Muwatha , 4 juz; (7) Al-Raddu 'alâ Ahl al-Bidî̀, 3 juz; (8) Al-Târîkh, 6 juz tapi tidak lengkap; (9) Thabaqât al-Ulamâ , 7 juz; (10) al-Asyribah wa Gharîb al-Hadis, 3 juz; (11) al-Îmân wa al-Radd 'alâ Ahl al-Syirk; (12) al-Hujjah

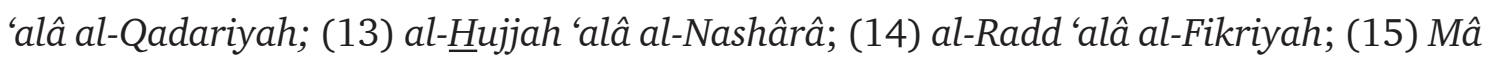
Yajibu 'alâ al-Mutanâdhirîn min $\underline{H} u s n$ al-Âdâb, 2 juz; (16) al-Wara'; (17) Syarh Arba'ah Kutub min Mudawwanah Sahnûn; (18) RisâlahfîMa'nâ al-Sunnah; (19) RisâlahfíMan Sabba al-Nabi SAW; (20) al-Ibâhah; (21) Âdâb al-Qâdhî; (22) Ahkkâm al-Qur'an. Semua kitab tersebut tidak ditemukan dan tidak diketahui keberadaannya. Kitab yang telah sampai ada saat ini adalah (23) Ajwibah Muhammad bin Sahnnûn ${ }^{21}$ dan (24) Âdâb al-Mu'allimîn atau alMu'allimîn wa al-Muta'allimîn. ${ }^{22}$

\footnotetext{
${ }^{18} \mathrm{Ibnu}$ Suhnûn, Kitâb Âdâb, h. 22 .

${ }^{19} \mathrm{Al}-\mathrm{Muzni}$ adalah di antara orang yang datang mendengar syarahan, yang banyak belajar, dan menghabiskan waktu bersama Ibnu Suhnûn. Lihat Prinsip-prinsip Pendidikan, h. 12

${ }^{20} \mathrm{Ibid}$, h. 25-27.

${ }^{21}$ Al-'Allâmah al-Syamqithî dalam lawatannya ke Andalusia berkata: Kitab ini adalah kitab yang tiada bandingannya dalam fikih, ada di Perpustakaan Oscoryal Asbania, terdaftar dengan nomor 1162. Di antaranya ada 3 naskah di Tûnis. Naskah pertama di perpustakaan al-Asyuriyah nomor indeks 424. Naskah kedua di perpustakaan al-Najjâriyah dan naskah ketiga di dua perpustakaan al-Khushûshiyah. Ibid, h. 27.

${ }^{22}$ Teks risalah Âdâb al-Mu'allimîn memuat 10 pembahasan, yaitu: Pembahasan pertama, hadis-hadis tentang keutamaan belajar dan mengajar al-Qur'an. Penulis lebih menekankan pengajaran al-Qur'an karena al-Qur'an adalah materi pertama dan utama yang harus diperkenalkan dan ditanamkan kepada anak didik sebelum mengajarkan materi-materi lain. Pembahasan kedua, hadis tentang berbuat adil kepada anak didik. Di sini dijelaskan tentang prinsip keadilan dan demokrasi dalam pendidikan. Penulis menginstruksikan kepada guru untuk berlaku adil kepada anak didik dan mengajarkan mereka dengan prinsip persamaan tanpa unsur diskriminasi jenis kelamin, status sosial dan warna kulit. Pembahasan ketiga tentang hal-hal yang makruh dalam menghapus nama Allah SWT. dan hal-hal yang seyogyanya dilakukan. Penulis menjelaskan bagaimana tata cara yang benar dan beretika menghapus kalam-kalam Allah yang ditulis anak didik di atas batu tulis sebagai media pencatatan ilmu. Pembahasan keempat hadis tentang adab (tata krama) menghukum anak, dan hukuman yang boleh dan yang tidak boleh. Di sini secara lebih khusus pemaparan mengenai prinsip-prinsip dan persyaratan-persyaratan penerapan metode
} 
Karya-karya intelektual Ibn Sahnûn tersebut mencakup berbagai disiplin ilmu pengetahuan, antara lain hadis, fikih, politik, tafsir hadis, tauhid, sejarah, akhlak, ilmu al-Qur'an, dan pendidikan. Dengan demikian, Ibn Sahnûn bisa dikatakan sebagai seorang muhaddits, fakih, politikus, mufasir dalam bidang hadis, teolog, sejarawan, pakar akhlak, pakar ilmu al-Qur'an, mutarjim (penulis biografi), dan paedagog Islam. Karya-karya tersebut menunjukkan kredibelitas Ibn Sahnûn sebagai seorang ulama yang menguasai berbagai disiplin ilmu dan memiliki pengetahuan yang luas dalam bidang ilmu-ilmu agama dan umum.

Berbekal ilmu yang luas dan akhlak mulia, kapasitas keulamaannya diakui dan dipuji oleh tokoh-tokoh yang hidup pada masanya. Di antaranya ialah sejarawan Afrika, Abû al-AArab al-Tamîmî al-Qairawânî berkata: "Ibn Sahnûn adalah imam dalam fikih, teliti, mengetahui atsar dan pada masanya tidak ada orang yang lebih memiliki (menguasai) berbagai macam disiplin ilmu dari padanya menurut yang saya ketahui." ${ }^{23}$ Seorang dokter Afrika yang sangat terkenal, Aḥmad bin al-Jazzâr dalam kitabnya al-Ta'rîf berkata: "Ibn Sahnûn adalah imam (pemimpin) pada masanya dalam madzhab ahl al-Madînah (madzhab Mâlik) di Maghrib (Marokko), faqîh, mengetahui atsar, pandai berdebat, mendalami hadis...". ${ }^{24}$

Dari penjelasan di atas dapat diketahui bahwa Ibn Sahnûn adalah seorang ulama yang sangat diakui keulamaan dan keilmuannya, sangat disegani, dihormati, dikagumi, menjadi contoh teladan bagi ulama-ulama pada masanya, dan berakhlak mulia. Karenanya, pada saat ia wafat, masyarakat Muslim di wilayah Maghrib khususnya mengalami duka mendalam dan merasa kehilangan seorang tokoh besar yang menjadi pemimpin agama di wilayah tersebut.

Ibn Sahnûn meninggal dunia pada tahun $256 \mathrm{H}$ dalam usia 54 tahun. Ia wafat setelah

hukuman yang benar yang sesuai dengan usia anak didik. Metode hukuman merupakan alternatif terakhir bila tidak mempan dengan metode pendidikan lainnya. Penerapan metode hukuman akan berdampak positif terhadap anak didik bila memperhatikan prinsip-prinsip dan persyaratanpersyaratan yang telah ditetapkan. Penerapan metode hukuman yang melampaui batas akan berdampak negatif terhadap anak dan ini termasuk metode hukuman yang harus dijauhi dan dilarang. Pembahasan kelima tentang khatam al-Qur'an dan apa yang harus dilakukan untuk guru. Penjelasannya mengenai kapan anak didik harus mengikuti khataman (ujian final) al-Qur'an dan status hukum guru menerima hadiah dari anak didik.Pembahasan keenam tentang pemberian hadiah kepada guru pada hari raya. Di sini lebih khusus menjelaskan status hukum pemberian hadiah kepada guru pada hari raya. Pembahasan ketujuh tentang hari libur dan murid yang absen. Di sini lebih spesifik memaparkan mengenai liburan mingguan dan tahunan serta apa yang harus dilakukan guru jika ada anak didik yang tidak hadir ke sekolah. Pembahasan kedelapan, kewajiban guru. Ibnu Suhnûn menetapkan banyaknya tugas yang harus dilakukan guru dalam proses belajar mengajar anak didik. Pembahasan kesembilan tentang penyewaan guru privat. Kajian detailnya mencakup kewajiban dan hak guru privat, sumber dana yang diambil untuk membayar gaji guru privat, dan perjanjian atau kesepakatan antara orang tua anak didik dengan guru privat tentang teknik pembayaran gaji mengajar serta hal-hal yang berkaitan dengannya. Pembahasan kesepuluh, penyewaan mushaf (al-Qur'an), kitab-kitab fikih, dan sebagainya. Ibnu Suhnûn memaparkan status hukum menyewa dan menjual al-Qur'an untuk dibaca dan pendapat para ulama tentang status penyewaan kitab-kitab fiqh dan lainnya. Ibid, h. 75-137.

${ }^{23}$ Ibid, h. 21.

${ }^{24}$ Ibid, h. 22. 
16 tahun berselang dengan kewafatan ayahnya. Ibn Sahnûn wafat di Sâhil dan dibawa oleh keluarganya ke Qairawân serta dikuburkan di Bâb Nâfi' di samping kubur ayahnya. ${ }^{25}$ Penghormatan yang tinggi yang diberikan oleh masyarakat pada zamannya terhadap ketokohan Ibn Sahnûn terlihat pada masa kewafatannya dimana pasar-pasar dan Kuttâb-Kuttâb ditutup karena menghormati kepergiannya. Banyak sekali umat Islam di daerah itu datang untuk menyalatkannya, termasuk Amîr dinasti al-Galibah, Ibrahîm bin Aḥmad bin al-Aglab di Qairawân. ${ }^{26}$

\section{Kuttâb: Pusat Pendidikan Dasar Islam}

Dari beberapa literatur yang dapat dipercaya ditemukan bahwa Kuttâb adalah institusi pendidikan dasar. ${ }^{27}$ Kuttâb merupakan tempat belajar membaca dan menulis yang berada di rumah guru dimana murid-murid berkumpul untuk menerima pelajaran. ${ }^{28}$ Kuttâb atau maktab diartikan sebagai tempat terbuka di luar rumah dimana guru mengajak para muridnya ke lapangan di sekitar masjid atau taman umum..$^{29} \mathrm{Kuttâb}$ biasanya diselenggarakan di luar masjid, meskipun kadang-kadang juga di dalam masjid karena kekurangan tempat di luar masjid. Selain itu, ada juga para guru yang menyelenggarakan pendidikan anak-anak di sudut-sudut masjid atau di bilik-bilik yang berhubungan dengan masjid. ${ }^{30}$

Berdasarkan kutipan di atas, diketahui bahwa Kuttâb merupakan tempat berlangsungnya proses belajar mengajar tingkat dasar, baik di rumah guru, tempat-tempat terbuka seperti lapangan di sekitar masjid atau taman umum, di dalam masjid, di pojok-pojok masjid ataupun di bilik-bilik yang berhubungan dengan masjid.

Secara historis, Kuttâb merupakan pusat pendidikan dasar tertua yang telah ada sejak masa pra Islam yang digunakan untuk belajar tulis-baca. ${ }^{31}$ Pada masa-masa awal Islam, keberadaan Kuttâb sebagai pusat pendidikan dasar yang khusus mengajarkan membaca dan menulis tetap dipertahankan. Namun, dalam perkembangan selanjutnya, Kuttâb

${ }^{25}$ Ibn Suhnûn, Kitab Âdab, h. 23.

${ }^{26}$ Suwito dan Fauzan (ed.), Sejarah, h. 53.

${ }^{27}$ Lihat Mansoor A. Quraishi, Some Aspects of Muslim Education (Lahore: Universal Books, 1983), h. 13, Mehdi Nakosteen, History of Islamic Origins of Western Education A. D. 800-1350 with an Introduction to Medieval Muslim Education (Colorado: University of Colorado Press, Boulder, 1964), h. 46, Bayard Dodge, Muslim Education in Medieval Times (Washington, D.C.: The Middle East Institute, 1962), h. 3, Khalil A. Totah, The Contribution of the Arabs to Education (New York City: Bureau of Publication Teacher College, Columbia University, 1926), h. 15, George Makdisi, The Rise of Colleges; Institutions of Learning in Islam and the West (Edinburgh: Edinburg University Press, 1981), h. 19, Ahmad Syalaby, Sejarah Pendidikan, h. 21.

${ }^{28}$ Mehdi Nakosteen, History of Islamic, h. 46. Lihat juga Mehdi Nakosteen, Kontribusi Islam atas Dunia Intelektual Barat: Deskripsi Analisis Abad Keemasan Islam, terj. Joko S. Kahhar dan Supriyanto (Surabaya: Risalah Gusti, 1994), h. 62.

${ }^{29}$ Charles Michael Stanton, Pendidikan Tinggi dalam Islam, terj. Afandi dan Hasan Asari (Jakarta: Logos, 1994), h. 19.

${ }^{30} \mathrm{Ibid}$, h. 49.

${ }^{31}$ Ahmad Syalabi, Sejarah Pendidikan, h. 33. 
dikembangkan menjadi institusi yang mengajarkan al-Qur'an. ${ }^{32}$ Sejak abad ke-II, Kuttâb telah berkembang pesat. Ibn Sahnûn, seorang pendidik abad ke-III H, al-Qâbisî, tokoh pendidikan abad ke-IV H, dan banyak para imam duduk di masjid atau di pojok-pojok masjid mengamati pelajaran Kuttâb, di mana terdapat anak-anak yang semangat dalam membaca dan menulis. ${ }^{33}$

Pendidikan di Kuttâb tertumpu kepada anak-anak di bawah umur 7 tahun (antara 5 dan 6 tahun), khususnya bagi anak laki-laki. Mereka akan menamatkan pendidikannya di lembaga tersebut dalam usia 13 dan 15 tahun. ${ }^{34}$ Al-Ahwânî menegaskan bahwa mayoritas anak yang belajar di Kuttâb tidak sampai kepada usia dewasa (marhalah al-bulûgh) dan hanya minoritas dari mereka sampai kepada usia remaja (sin al-ihtilâm). Jika seorang anak mempelajari al-Qur'an sejak usia 6 tahun, ia hanya memerlukan waktu yang singkat, yaitu antara 4 dan 5 tahun sehingga mampu menghapal ayat-ayat al-Qur'an. Karena itu anakanak yang pintar dapat mengkhatam al-Qur'an pada usia 10 tahun dibandingkan anak-anak lain yang biasanya menghabiskan bacaan mereka dalam usia 12 dan 15 tahun. ${ }^{35}$

\section{Praktik Kurikulum Pengajaran di Insitusi Pendidikan Dasar Islam sebelum dan pada Masa Ibn Sahnûn}

Sejak Kuttâb lahir sebagai institusi pendidikan dasar Islam, sejak saat itu kurikulum pengajaran lembaga tersebut mulai dipraktikkan. Tidak terkecuali pada era pra Ibn Sahnûn, terutama sekali pada masa Rasulullah SAW. khulafâ al-râsyidîn, dan bani Umayah. Pada masa Nabi SAW. di Madinah, kurikulum pengajaran di lembaga tersebut terdiri atas: 1) Membaca, 2) Keimanan (rukun iman), 3) Ibadah (rukun Islam), 4) Akhlak, 5) Dasar ekonomi, 6) Dasar politik, 7) Olah raga dan kesehatan (pendidikan jasmani), dan 8) Membaca dan menulis. ${ }^{36}$

Pada era khulafâ' al-râsyidîn dan bani Umayah kurikulum pengajaran di lembaga pendidkan dasar Islam telah bertambah, tetapi tidak berarti. Secara ringkas kurikulum pendidikan dasar pada masa iniadalah: 1) Membaca dan menulis, 2) Membacaal-Qur'an dan menghafalkannya, 3) Keimanan, ibadah, dan akhlak. 'Umar bin al-Khaththâb menginstruksikan kepada penduduk kota supaya kepada anak-anak diajarkan berenang, menunggang kuda, memanah, membaca dan menghafal syair yang mudah dan peribahasa. ${ }^{37}$ 'Umar bin al-Khaththâb menginstruksikan

${ }^{32}$ Ibid, h. 34.

${ }^{33}$ Ali al-Jumbulati dan Abdul Futuh at-Tuwaanisi, Perbandingan Pendidikan Islam, terj. M. Arifin (Jakarta: Rineka Cipta, 2002), h. 29.

${ }^{34}$ Zakaria, Prinsip-Prinsip Pendidikan, h. 35.

${ }^{35}$ Ahmad Fuâd al-Ahwânî, Al-Tarbiyah fì al-Islâm (al-Qâhirah: Dâr al-Ma'ârif, duna alsanah), h. 15 .

${ }^{36}$ Ahmad Tafsir, Ilmu Pendidikan dalam Perspektif Islam (Bandung: Remaja Rosdakarya, 2004), h. 59-60.

${ }^{37}$ Ibid. 
perlunya kepada anak diajarkan materi-materi tersebut jika mereka telah mengenal dasardasar agama Islam, menghapal al-Qur'an, dan menguasai hadis. ${ }^{38}$

Pada era Ibn Sahnûn dan keemasan Islam di bawah kekuasaan bani 'Abbâsiyah, praktik kurikulum pengajaran di pusat pendidikan dasar Islam berbeda antara satu negeri Islam dengan negeri Islam lainnya. Di Marokko, anak-anak hanya diajarkan al-Qư’an dan dipentingkan tulisannya, tidak dicampur dengan materi lain, seperti hadis, fikih, syair atau natsar. Di Andalusia diajarkan al-Qur'an dan menulis, serta dicampurkan dengan materi syair, atsar, dasar-dasar nah wu, sharaf, dan tulisan indah. Di Afriqiyah (Tunisia), dicampurkan pelajaran al-Qur'an dengan hadis dan dasar-dasar ilmu agama, tetapi hafalan al-Qur'an sangat dipentingkan. Di Timur (Irak dan sekitarnya) dipentingkan pelajaran al-Qur'an dan bermacam-macam bidang ilmu serta kaedah-kaedahnya, tapi tidak dipentingkan tulisan indah, cukup tulisan biasa saja. ${ }^{39}$

Secara konkrit, ada perbedaan antara praktik kurikulum pengajaran di pusat pendidikan dasar Islam pada era sebelum Ibn Sahnûn dengan pada masa Ibn Sahnûn sendiri. Perbedaannya, praktik kurikulum pengajaran di lembaga tersebut pada era pra Ibn Sahnûn memperhatikan aspek rohani (hati), akal, dan jasmani. Sementara pada masa Ibn Sahnûn, praktik kurikulum pengajaran di pusat pendidikan dasar Islam tersebut hanya mementingkan aspek rohani (hati) dan akal. Aspek jasmani kurang mendapat perhatian.

Pada era Ibn Sahnûn di Afrika Utara, Kuttâb sebagai lembaga pendidikan dasar Islam memainkan peranan penting dan pengaruh yang besar dalam sistem pendidikan Islam. Di Kuttâb berkumpul anak-anak dari berbagai latar belakang lingkungan keluarga, baik anak orang kaya maupun anak orang miskin, dan sebagainya. Meskipun demikian, di lembaga ini tidak terjadi unsur-unsur pendidikan yang bersifat diskriminatif. Bahkan sebaliknya, prinsip-prinsip kebebasan dan demokrasi tercermin di dalam sistem pendidikan Kuttâb. ${ }^{40}$

Pada era Ibn Sahnûn, Kuttâb telah jadi institusi pendidikan dasar Islam formal. Pendidikan di Kuttâb juga telah berkembang secara mantap dan sistematis. Di antara aspek utama yang mengukuhkan keberadaan Kuttâb sebagai pusat pendidikan dasar Islam pada zaman Ibn Sahnûn adalah kurikulum.

\section{Pemikiran Ibn Sahnûn tentang Kurikulum Pengajaran di Insitusi Pendidikan Dasar Islam}

\section{Pengertian Kurikulum}

Abuddin Nata mengartikan kurikulum sebagai bahan pengajaran yang terangkum pada sejumlah mata pelajaran yang harus dipelajari sampai selesai/tamat dari suatu unit

\footnotetext{
${ }^{38}$ Muhammad 'Athiyah al-Abrâsyî, Al-Tarbiyah al-Islâmiyah (t.t.p.: t.p., t.t.), h. 141 .

${ }^{39}$ Mahmud Yunus, Sejarah Pendidikan Islam (Jakarta: Mahmud Yunus Wadzurriyah, 2008), h. 50

${ }^{40} \mathrm{Al}-J u m b u l a t i$ dan al-Tuwaanisi, Perbandingan, h. 30.
} 
pendidikan dengan bukti mendapatkan suatu gelar, pengakuan ataupun ijazah. ${ }^{41}$ Menurut Ahmad Tafsir, kurikulum minimal memiliki tiga pengertian, yaitu kurikulum dalam arti sejumlah mata pengajaran pada suatu jenjang unit pendidikan, kurikulum dalam arti silabus, dan kurikulum dalam arti program sekolah. Pengertian kurikulum terakhir inilah yang paling luas. ${ }^{42}$ Dari pengertian kurikulum yang dikemukakan di atas, secara umum ada dua pengertian kurikulum, yaitu kurikulum dalam arti sempit dan kurikulum dalam arti luas. Dewasa ini, istilah kurikulum yang sesuai dipraktikkan dalam semua jenjang pendidikan adalah kurikulum dalam arti luas, bukan dalam arti sempit.

Dalam literatur pendidikan Islam, istilah kurikulum dikenal dengan kata manhaj, jamaknya, manâhij. Bila dikaitkan dengan pendidikan, maka manhaj adalah jalan terang yang dilalui pendidik dengan anak didik untuk mengembangkan pengetahuan, keterampilan, dan sikap mereka. ${ }^{43}$ Bagaimanapun, Ibn Sahnnûn sendiri tidak memberikan definisi kurikulum (manhaj) dalam karya-karyanya. Berdasarkan kepada sistem pendidikan di pusat-pusat pendidikan dasar Islam pada zamannya, Ibn Sahnûn memandang kurikulum dalam ruang lingkup yang luas, tidak hanya terbatas pada skop mata pelajaran khusus dalam kelas semata, melainkan mencakup pengalaman pendidikan di luar institusi pendidikan dasar Islam. Hal ini bisa dicermati dari pernyataan Ibn Sahnûn, yaitu "murid-murid turut dilibatkan dalam masyarakat untuk melakukan doa minta hujan bersama ketika datang musim kemarau." ${ }^{44}$

\section{Klasifikasi Kurikulum}

Kurikulum institusi pendidikan dasar Islam menurut Ibn Sahnûn dapat diklasifikasikan kepada dua macam, yaitu kurikulum wajib (ijbâri) dan kurikulum pilihan (ikhtiyâri). Materimateri ijbâri adalah materi-materi pelajaran yang wajib diajarkan guru kepada anak didik, yaitu: 1) al-Qur'an. Materi-materi tentang al-Qur'an yang harus diajarkan adalah tauqîf (tanda-tanda berhenti dalam al-Qur'an), syakl (tulisan berbaris), i'râb, rasm, imla', qirâ'ah hasanah yaitu qirâ'ah nâfi', dan khat hasan (tulisan yang bagus); 2) Fikih. Materi-materi tentang Fikih yang harus diajarkan adalah wudhû, shalât (jumlah rak'at, sujûd, bacaan dalam shalât, takbîr, cara duduk, ihnrâm, salâm, bacaan-bacaan lain yang wajib dibaca dalam shalât, tasyâhud, dan qunût dalam shalât shubuh, dan macam-macam shalât sunat, seperti shalât sunat fajar dua rakaat, witir, shalât dua hari raya, shalât minta hujan, shalât gerhana, shalât janâzah serta doa-doanya), doa-doa; dan 3) akhlak. ${ }^{45}$

${ }^{41}$ Abuddin Nata, Filsafat Pendidikan Islam (Jakarta: Logos Wacana Ilmu, 1997), h. 123.

${ }^{42} \mathrm{Ahmad}$ Tafsir, Filsafat Pendidikan Islami: Integrasi Jasmani, Rohani dan Kalbu Memanusiakan Manusia (Bandung: Remaja Rosdakarya, 2006), h. 102-103.

${ }^{43}$ Omar Mohammad al-Toumy al-Syaibany, Falsafah Pendidikan Islam, terj. Hasan Langgulung (Syah Alam: HIZBI, 1991), h. 478.

${ }^{44}$ Ibnu Suhnûn, Kitâb Âdâb, h. 111.

${ }^{45}$ Ibid, h. 102-112. 
Adapun materi-materi ikhtiyâri adalah materi-materi pelajaran yang tidak wajib diajarkan guru kepada anak didik. Materi-materi pelajaran tersebut sifatnya pilihan, guru boleh mengajarkan atau tidak mengajarkannya. Tetapi kalau materi-materi tersebut sangat dibutuhkan (urgen) maka guru wajib mengajarkannya kepada anak didik. Materi-materi tersebut adalah matematika, syair, bahasa asing, bahasa Arab, khat (kaligrafi), semua cabang ilmu gramatikal bahasa (seperti, ilmu nahwu, dan lainnya), sejarah bangsa Arab, menulis surat (korespondensi), dan pidato. ${ }^{46}$

Ringkasan klasifikasi materi-materi pelajaran yang diajarkan di institusi pendidikan dasar Islam ini dapat dilihat dalam tabel berikut:

\begin{tabular}{|c|c|}
\hline Mata Pelajaran Wajib & $\begin{array}{c}\text { Mata Pelajaran Pilihan } \\
\text { (Wajib berdasarkan keperluan) }\end{array}$ \\
\hline $\begin{array}{l}\text { Al-Quran } \\
\text { tauqîf (tanda-tanda berhenti dalam } \\
\text { al-Qur'an), } \\
\text { syakl (tulisan berbaris), i'râb, rasm, } \\
\text { imlâ', } \\
\text { qirâ'ah hasanah yaitu qirâ'ah nâfi', } \\
\text { dan } \\
\text { khat hasan (tulisan yang bagus) }\end{array}$ & $\begin{array}{l}\text { Bahasa } \\
\text { Bahasa Asing } \\
\text { Bahasa Arab } \\
\text { Cabang ilmu bahasa seperti } \\
\text { tatabahasa } \\
\text { Korespondensi } \\
\text { Pidato } \\
\text { Syair }\end{array}$ \\
\hline $\begin{array}{l}\text { Fikih } \\
\text { Wudhu' } \\
\text { Shalat } \\
\text { Doa }\end{array}$ & Matematika \\
\hline Akhlak & Sejarah \\
\hline
\end{tabular}

Tabel 1: Klasifikasi Mata Pelajaran untuk Murid Pendidikan Dasar Islam menurut Ibn Sahnûn

Menurut Ibn Sahnûn ada tiga kategori kurikulum yang diajarkan kepada anak didik di Kuttâb, yaitu kurikulum primer, kurikulum sekunder, dan kurikulum sebagai alat bantu pemahaman. Kurikulum primer adalah mata pelajaran yang menjadi inti ajaran Islam, seperti al-Qur'an, fikih, dan akhlak. Kurikulum sekunder merupakan mata pelajaran yang menjadi pendukung untuk memahami Islam, seperti matematika dan sejarah. Kemudian kurikulum sebagai alat bantu pemahaman yaitu mata pelajaran yang berkaitan dengan ilmu bahasa (linguistik), seperti bahasa Arab dan cabang-cabang ilmu bahasa Arab, bahasa asing lainnya, syair, korespondensi, dan pidato.

Berdasarkan tabel di atas, kurikulum yang disusun oleh Ibn Sahnûn memperlihatkan keseimbangan antara ilmu-ilmu keagamaan (ukhrawi) dengan ilmu-ilmu yang bersifat keduniaan (duniawi). Karena Ibn Sahnûn hidup pada zaman yang sejajar dengan era kemajuan

${ }^{46}$ Ibid, h. 102-104. 
dan keemasan Islam, patut diduga bahwa ciri-ciri kurikulum yang ia tawarkan turut memperlihatkan ciri keseluruhan kurikulum pendidikan pada zaman tersebut.

Senada dengan pernyataan di atas, Hasan Langgulung menguatkan bahwa keseimbangan antara ilmu-ilmu agama dan ilmu-ilmu dunia hanya ada pada era-era keemasan (golden age) Islam. Keseimbangan ini hilang pada era kelemahan. ${ }^{47}$ Keseimbangan kurikulum pendidikan di tingkat dasar bermuara pada pengkhususan bidang dan ilmu di tingkat yang lebih tinggi, sesuai dengan perkembangan masa, jenjang pendidikan, lembaga pendidikan dan sebagainya.

Tabel di atas juga memperlihatkan bahwa ilmu-ilmu keagamaan perlu dipelajari oleh pelajar secara terperinci terutama sekali ilmu-ilmu tentang pokok-pokok ajaran agama. Pembelajaran al-Quran sebagai contoh, tidak hanya merujuk kepada kemampuan membaca al-Quran tetapi turut meliputi kemampuan membaca dengan baik, kemampuan menulis dan lain-lain. Pembelajaran ilmu fikih tidak hanya meliputi aspek teoritis, tetapi juga praktis. Berkaitan dengan ilmu-ilmu keduniaan, walaupun diwajibkan di pusat-pusat pendidikan dasar, Ibn Sahnûn tidak menetapkan mata pelajaran yang khusus, karena pemilihan mata pelajaran sangat tergantung kepada kehendak orang tua anak didik dan tuntutan masyarakat.

Meskipun kurikulum pendidikan yang didesain oleh Ibn Sahnûn di lembaga pendidikan dasar Islam pada masa awal memiliki bentuk yang sederhana, tetapi kurikulum pendidikan tersebut bertujuan menanamkan pendidikan berdasarkan norma-norma ajaran Islam dan penerapan kurikulum sejajar dengan falsafah Islam yang mengajak manusia mengaitkan pengetahuannya dengan nilai-nilai keislaman.

Rancangan kurikulum tersebut menunjukkan bahwa menurut Ibn Sahnûn integrasi antara dunia dan akhirat di dalam pendidikan Islam demikian penting. Ia menginginkan supaya umat Islam tidak menfokuskan kepada duniawi semata tetapi juga mementingkan ukhrawi. Dengan demikian pendidikan Islam menurut Ibn Suhnun tidak hanya difokuskan pada ilmu-ilmu akhirat saja tetapi juga mencakup ilmu-ilmu dunia. Hal ini penting agar umat manusia dapat mempersiapkan diri untuk kehidupan dunia dan akhirat. Untuk itulah Ibn Sahnûn menyusun kurikulum pendidikan yang seimbang antara kepentingan duniawi dengan ukhrawi.

Berdasar paparan di atas dapat disimpulkan bahwa di antara prinsip penyusunan kurikulum pengajaran di lembaga pendidikan dasar menurut Ibn Sahnûn ialah prinsip tawâzun (keseimbangan), yaitu keseimbangan antara materi-materi agama (ukhrawi) dengan materi-materi umum (duniawi) atau keseimbangan antara aspek intelektual dengan spiritual dan antara materi-materi yang teoritis dengan yang praktis. Selain itu, Ibn Sahnûn juga tampaknya mementingkan prinsip relevansi, yaitu kesesuaian kurikulum dengan kebutuhan atau tuntutan masyarakat. Karenanya di antara dasar utama yang menjadi landasan penyusunan kurikulum pengajaran tersebut adalah dasar agama dan dasar sosial.

\footnotetext{
${ }^{47}$ Hasan Langgulung, Asas-asas Pendidikan Islam (Jakarta: Pustaka Al-Husna, 1987), h. 117.
} 


\section{Rekomendasi dan Kritik terhadap Kurikulum Pengajaran Ibn Sahnûn}

Ibn Sahnûn hidup pada abad ke-3 H/ke-9 M, yakni era puncak kemajuan dan kejayaan Islam (golden age). Dengan demikian, kurikulum pendidikan dasar Islam yang disusunnya adalah kurikulum pendidikan dasar Islam yang sesuai dengan lingkungan masyarakat era keemasan Islam di tempat dan pada masa Ibn Sahnûn hidup. Jadi, desain kurikulum pendidikan dasar pada masanya tentu saja sangat dipengaruhi oleh kondisi dan kebutuhan atau tuntutan masyarakat pada masa itu, yang berbeda dengan kondisi dan kebutuhan atau tuntutan masyarakat pada masa kini. Dengan demikian, maka kurikulum pendidikan dasar Islam yang telah disusun oleh Ibn Sahnûn pada masanya, yakni \pm 12 abad yang lalu bisa saja masih relevan, dapat dipertahankan, atau masih signifikan untuk dipraktekkan di lembagalembaga pendidikan dasar dewasa ini, di samping perlu juga dikritisi.

Kurikulum pendidikan dasar Ibn Sahnûn perlu dipertahankan dan dipraktekkan di institusi-institusi tingkat dasar, baik milik pemerintah atau swasta, yayasan atau pribadi, maupun Sekolah Dasar (SD) atau Madrasah Ibtidaiyah (MI). Hal ini penting karena sangat relevan untuk menanamkan dasar-dasar agama pada usia anak-anak sehingga kelak mereka akan menjadi individu Muslim yang taat kepada Allah SWT. Ibn Sahnûn memasukkan ilmu-ilmu agama dalam kurikulum wajib menunjukkan bahwa ilmu-ilmu agama tersebut harus lebih dahulu diajarkan kepada anak-anak sekolah dasar daripada ilmu-ilmu lain.

Kurikulum yang lebih mengutamakan ilmu-ilmu agama daripada ilmu-ilmu lain dalam pengajaran justeru akan mengukuhkan eksistensi pribadi Muslim dalam menghadapi berbagai tantangan modernisasi dan globalisasi yang cenderung membawa manusia ke arah materialistik, individualistik, hedonistik, eklusifistik, dan yang lebih parah lagi dekadensi moral yang melanda hampir semua aspek kehidupan manusia. Tentu saja untuk mengantisipasi berbagai dampak negatif tersebut, keberadaan kurikulum pendidikan tingkat dasar yang lebih mengutamakan materi-materi agama menemukan signifikansinya.

Kurikulum pendidikan dasar versi Ibn Sahnûn sangat signifikan dipraktekkan dalam pelaksanaan pendidikan dasar dewasa ini dikarenakan dalam kurikulum yang ditawarkan Ibn Sahnûn terdapat keseimbangan materi-materi agama dengan materi-materi umum Dengan demikian output yang dilahirkan dari jenjang pendidikan tersebut tidak hanya cerdas aspek kognitif, afektif, dan psikomotorik, tetapi juga cerdas spiritual. Berbeda halnya dengan kurikulum pendidikan dasar dewasa ini, di mana output yang dilahirkan lebih menguasai aspek kognitif dari hampir semua mata pelajaran yang mereka pelajari ketimbang aspek lainnya.

Meskipun beberapa aspek kurikulum pendidikan dasar versi Ibn Sahnûn memiliki nilai plus, namun dari aspek lain menurut penulis masih memiliki kekurangan. Kekurangannya adalah Ibn Sahnûn tidak memasukkan pendidikan jasmani ke dalam mata pelajaran kurikulum pendidikan dasar yang didesainnya, padahal pendidikan jasmani juga penting bagi anakanak dan dianjurkan dalam Islam. Di lembaga pendidikan dasar pada era awal Islam, pendidikan 
jasmani, seperti menunggang kuda, berenang dan lainnya dimasukkan ke dalam kurikulum, di samping materi al-Qur'an, puisi, peribahasa terkenal, ilmu hitung, tata bahasa, adab-adab, dan keterampilan menulis indah. ${ }^{48}$

Ibn Sahnûn tidak menjelaskan alasan mengapa beliau tidak memasukkan pendidikan jasmani ke dalam kurikulum pendidikan dasar pada masanya itu. Tetapi menurut analisis

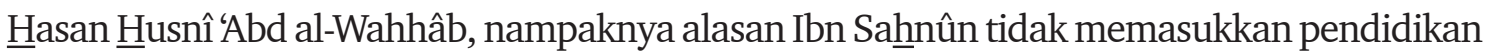
jasmani ke dalam kurikulum pendidikan dasar karena pada hari-hari libur sekolah, terutama libur Jum'at, anak-anak bisa memanfaatkan waktu-waktu istirahat tersebut untuk berolah raga sendiri ${ }^{49}$ menurut kesukaan masing-masing. Menurut penulis, pendidikan jasmani harus tetap dimasukkan ke dalam kurikulum sekolah karena dalam prakteknya pendidikan jasmani tidak terlepas dari bimbingan guru. Apa saja materi pendidikan yang diberikan di sekolah, apalagi materi pendidikan jasmani untuk anak-anak tingkat dasar, tentu saja harus dalam pengawasan guru. Kalau tidak, maka pendidikan tersebut tidak terarah dan tidak mencapai tujuan yang diharapkan.

Kemudian kurikulum pendidikan dasar Ibn Sahnûn tidak terlihat materi pendidikan keimanan secara konkret. Padahal, selain ibadah dan akhlak, iman juga termasuk pokok dalam agama Islam. Karenanya pendidikan dasar keagamaan sebenarnya harus mencakup aspek keimanan (rukun iman), ibadah (rukun Islam), dan akhlak. Ini adalah aspek-aspek dasar yang harus diperhatikan. Kalau tidak atau kurang diperhatikan, maka tujuan pendidikan yang hakiki tidak atau kurang tercapai.

Pendidikan keimanana adalah pendidikan pertama dan utama diajarkan kepada anak, apalagi anak-anak yang sudah sampai usia sekolah dasar. Pendidikan keimanan membekali anak dengan dasar-dasar iman, rukun Islam, dan dasar-dasar syari’ah, sejak anak mulai mengerti dan memahami sesuatu. Tujuan dasar pendidikan ini adalah agar anak hanya mengenal Allah SWT. sebagai Khaliqnya, Islam sebagai agamanya, al-Qur'an sebagai imamnya, dan Rasulullah SAW. sebagai utusan Allah SWT. yang patut diteladani. ${ }^{50}$ Kurikulum pendidikan pada era Rasulullah SAW., khulafâ al-râsyidîn, dan bani Umayah seperti penjelasan terdahulu tetap menjadikan pendidikan keimanan sebagai materi pokok. Mengenai pendidikan keimanan ini, Ibn Sahnûn tidak memberi alasan mengapa beliau tidak memasukkan pendidikan keimanan ke dalam kurikulum pendidikan tingkat dasar pada masanya.

Selain itu, kurikulum pendidikan dasar yang diklasifikasikan Ibn Sahnûn kepada kurikulum wajib dan pilihan tidak selamanya bertahan seperti itu, karena boleh jadi pasca era beliau pembagian kurikulum seperti itu tidak sesuai lagi. Karenanya, tentu kurikulum memerlukan perubahan dan pengembangan sesuai dengan tuntutan masa. Kadang-kadang

${ }^{48}$ Nakosteen, History of Islamic, h. 46.

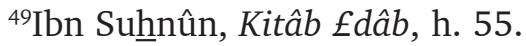

${ }^{50} \mathrm{Abdul}$ Kholiq, et al, Pemikiran Pendidikan Islam; Kajian Tokoh Klasik dan Kontemporer, (Semarang: Fakultas Tarbiyah IAIN Walisongo, 1999), h. 62. 
materi pelajaran dalam kurikulum pilihan bisa dimasukkan ke dalam kelompok kurikulum wajib, seperti al-Qâbisî, memasukkan materi Bahasa Arab (dasar-dasar Bahasa Arab) ${ }^{51}$ ke dalam kelompok kurikulum wajib. Berbeda dengan al-Qâbisî, Ibn Sahnûn memasukkan materi Bahasa Arab ke dalam kelompok kurikulum pilihan. Untuk masa sekarang, kurikulum pendidikan dasar tidak perlu adanya klasifikasi kurikulum semacam itu, karena cukup dijadikan sebagai suatu kesatuan yang terintegrasi.

\section{Penutup}

Kurikulum pengajaran pendidikan dasar Islam Ibn Sahnûn, dari satu sisi, relevan dengan praktik kurikulum pengajaran pendidikan dasar Islam selama ini, terutama dilihat dari dua hal. Pertama, aspek prinsip penyusunannya, yaitu prinsip tawâzun (keseimbangan) antara materi-materi ukhrawi dengan duniawi (aspek intelektual dengan spiritual), antara materi-materi yang teoritis dengan yang praktis, dan prinsip relevansi, yaitu kesesuaian kurikulum pengajaran tersebut dengan kebutuhan masyarakat. Kedua, aspek dasar utama yang menjadi landasan penyusunan kurikulum pengajaran, yaitu dasar agama dan sosial.

Pemikiran Ibn Sahnûn tentang kurikulum pendidikan dasar Islam, khususnya berkaitan dengan prinsip dan dasar utama yang menjadi landasan penyusunan kurikulum tersebut memiliki arti penting dan harus dipertahankan untuk dipraktikkan pada lembaga pendidikan dasar Islam masa kini dan akan datang.

\section{Pustaka Acuan}

Quraishi, Mansoor A. Some Aspects of Muslim Education. Lahore: Universal Books, 1983.

A. Totah, Khalil. The Contribution of the Arabs to Education. New York City: Bureau of Publication Teacher College, Columbia University, 1926.

Abdul Nasir Zakaria, Gamal. Prinsip-Prinsip Pendidikan Islam. Ibn Sahnun, al-Qabisi, Ibn Khaldun. Pahang Darul Makmur: PTS Publications \& Distributors SDN BHD, 2003.

Al-Abrâsyi, Muhammad 'Athiyah. Al-Tarbiyah al-Islâmiyah. t.t.p.: t.p., t.t.

Al-Ahwâni, Aḥmad Fuâd. Al-Tarbiyah fí al-Islâm. Kairo: Dâr al-Ma‘ârif, duwna al-sanah.

Al-Ahwâni, Ahmad Fuâd. Al-Tarbiyah fí al-Islâm aw al-Ta lîm fí Ra yi al-Qâbisi. al-Qâhirah: Dâr Ihyâ al-Kutub al-'Arabiyah 'îsâ al-Bâbi al-ㅍalabi wa Syurakâhu, 1955.

Ali Al-Jumbulati dan Abdul Futuh Al-Tuwaanisi. Perbandingan Pendidikan Islam. terj. M. Arifin. Jakarta: Rineka Cipta, 2002.

Al-Syaibany, Omar Mohammad al-Toumy. Falsafah Pendidikan Islam, terj. H. Langgulung. Syah Alam: HIZBI, 1991.

${ }^{51}$ Aḥmad Fuâd al-Ahwânî, Al-Tarbiyah fí al-Islâm aw al-Ta lîm fî Ra yi al-Qâbisi (al-Qâhirah: Dâr Ihyâ al-Kutub al-AArabiyah 'îsâ al-Bâbi al-Halabi wa Syurakâhu, 1955), h. 158. 
Asyraf, Ali. Horizon Baru Pendidikan Islam. t.t.p.: Pustaka Firdaus, 1996.

Dodge, Bayard. Muslim Education in Medieval Times. Washington, D.C.: The Middle East Institute, 1962.

Furchan, Arief et al. Pengembangan Kurikulum Berbasis Kompetensi di Perguruan Tinggi Islam. Yogyakarta: Pustaka Pelajar, 2005.

Ismail, Sya'ban Muftah. Muhammad Ibn Sahnun: An Educationalist and a Faqih. Muslim Education Quarterly, Vol. 12, No. 4. U.K.: The Islamic Academy, Cambridge, 1995.

Kholiq, Abdul et al. Pemikiran Pendidikan Islam; Kajian Tokoh Klasik dan Kontemporer. Semarang: Fakultas Tarbiyah IAIN Walisongo, 1999.

Langgulung, Hasan. Asas-asas Pendidikan Islam. Jakarta: Pustaka Al-Husna. 1987.

Makdisi, George. The Rise of Colleges: Institutions of Learning in Islam and the West. Edinburgh: Edinburg University Press, 1981.

Nakosteen, Mehdi. History of Islamic Origins of Western Education A. D. 800-1350 with an Introduction to Medieval Muslim Education. Colorado: University of Colorado Press, Boulder, 1964.

Nakosteen, Mehdi. Kontribusi Islam atas Dunia Intelektual Barat: Deskripsi Analisis Abad Keemasan Islam, terj. Joko S. Kahhar dan Supriyanto. Surabaya: Risalah Gusti, 1994.

Nata, Abuddin. Filsafat Pendidikan Islam. Jakarta: Logos Wacana Ilmu, 1997.

Stanton, Charles Michael. Pendidikan Tinggi dalam Islam, terj. Afandi dan Hasan Asari. Jakarta: Logos, 1994.

Sahnûn, Muhammad bin. Kitâb Âdâb al-Mu'allimîn. Tunisia: Dâr Buwsalâmah li al-Thab'ah wa al-Nasyr wa al-Tauzî̀, t.t.

Susanto, A. Pemikiran Pendidikan Islam. Jakarta: Amzah, 2009.

Suwito dan Fauzan (ed.). Sejarah Pemikiran Para Tokoh Pendidikan. Bandung: Angkasa, 2003.

Syalaby, Ahmad. Sejarah Pendidikan Islam (Terj. S. L. Muchtar Jahja). Singapura: Pustaka Nasional, 1976.

Syâfi'i, Ismâ'îl Muhammad. Min A'lâm al-Tarbiyah al-Arabiyah al-Islâmiyah. Maktabah al-Tarbiyah al-Aaraby li Duwal al-Khalîj, 1988.

Tafsir, Ahmad. Ilmu Pendidikan dalam Perspektif Islam. Bandung: Remaja Rosdakarya, 2004.

Tafsir, Ahmad. Filsafat Pendidikan Islami; Integrasi Jasmani, Rohani dan Kalbu Memanusiakan Manusia. Bandung: Remaja Rosdakarya, 2006.

Yunus, Mahmud. Sejarah Pendidikan Islam. Jakarta: Mahmud Yunus Wadzurriyah, 2008.

Z. Syams al-Dîn, 'Abd al-Amîr. Al-Fikr al-Tarbawi 'inda Ibn Sahnûn wa al-Qâbisî. al-Thab'ah al-Ulâ. Bairut: al-Syirkah al-'Islamiyah li al-Kitâb, 1990. 